\title{
An Analysis of Early Reading Ability of Class 1 in Elementary School
}

\section{Analisis Kemampuan Membaca Permulaan Kelas 1 Sekolah Dasar}

\author{
Desak Putu Anom Janawati*, I Made Eka Sulantara \\ Pendidikan Guru Sekolah Dasar, STKIP Suar Bangli, Indonesia
}

OPEN ACCESS

ISSN 25482254 (online) ISSN 20893833 (print)

Edited by:

Cahyo Hasanudin

Reviewed by:

Ari Metalin Ika Puspita

*Correspondence:

Desak Putu Anom Janawati

desakjanawati@gmail.com

Received: 3 Agustus 2020 Accepted: 11 Desember 2020

Published: 21 Desember 2020

Citation:

Janawati DPA and Sulantara IME (2021) An Analysis of Early Reading

Ability of Class 1 in Elementary

School.

Pedagogia: Jurnal Pendidikan. 10:1. doi: 10.21070/pedagogia.v10vi1i.6
This study aimed at describing early reading ability of Elementary School students. This is a qualitative descriptive research. The samples were class I students in Elementary School in total of 22 students, comprising of 11 males and 11 females. The data were collected by using observation sheet and test of early reading ability. The data were analyzed by using Likert scale. The research finding showed that early reading ability of Elementary School students in SD Negeri 3 Ubud was categorized as good (B) with 85\% percentage.

Keywords: Early Reading Ability

Penelitian ini bertujuan untuk menggambarkan kemampuan membaca permulaan di Sekolah Dasar. Jenis penelitian ini merupakan penelitian deskriptif kualitatif . Sampel yang digunakan dalam penelitian ini adalah siswa kelas I SD yang berjumlah 22 orang yang terdiri dari 11 siswa laki-laki dan 11 siswa perempuan. Data yang dikumpulkan dalam penelitian ini menggunakan lembar observasi dan tes kemampuan membaca permulaan. Data dianalisis dengan Teknik skala Likert. Hasil penelitian menunjukkan bahwa kemampuan membaca permulaan kelas I SD Negeri 3 Ubud termasuk dalam kategori baik (B) dengan persentase mencapai $85 \%$.

Kata Kunci: Kemampuan Membaca Permulaan 


\section{PENDAHULUAN}

Setelah menempuh jenjang pendidikan tamann kanak-kanak (TK) peserta didik akan menempuh jenjang pendidikan yaitu sekolah dasar (SD). Pada tahap ini peserta didik duduk di kelas I sekolah dasar yang sering juga disebut sebagai kelas awal. Pembelajaran yang ditekankan di kelas awal khususnya dalam pembelajaran Bahasa Indonesia salah satunya adalah keterampilan membaca permulaan. Membaca permulaan adalah salah satu pembelajaran Bahasa Indonesia yang diberikan di kelas rendah atau kelas awal yaitu pada kelas I, II dan III dengan menekankan pada pengenalan huruf dan bunyi Bahasa Rahim (2005). Kegiatan membaca permulaan di kelas awal lebih berfokus pada menyuarakan simbol dalam bentuk tulisan dengan tepat dan benar. Di kelas I peserta didik belajar mengenal huruf, setelah mengenal huruf peserta didik belajar mengenal suku kata dan kata sederhana yang bermakna, kemudian kata-kata sederhana dikembangkan menjadi kalimat sederhana yang dikenalkan ketika peserta didik kelas II, kelas I dan kelas dua peserta didik diberikan dasar - dasar kemampuan membaca yang akan mempengaruhi kemampuan membaca tingkat lanjut Masykuri (2019).

Keterampilan bahasa Indonesia mencangkup empat aspek yakni: membaca, menulis, menyimak dan mendengarkan. Keempat keterampilan ini saling terkait satu sama lain sehingga melalui penguasaan keempat keterampilan berbahasa siswa dikatakan terampil berbahasa. Pemerolehan keempat keterampilan berbahasa tersebut bersifat hierarkis. Artinya pemerolehan keterampilan berbahasa yang satu akan mendasari keterampilan yang lainnya. Keterampilan menyimak dan berbicara pertama kalinya didapatkan dalam lingkungan keluarga atau rumah. Keterampilan membaca dan menulis diperoleh ketika memasuki usia sekolah. Pembelajaran membaca menulis merupakan sajian pembelajaran yang awal dan utama bagi peserta didik di sekolah dasar pada kelas awal atau kelas rendah. Keterampilan membaca menulis permulaan dikemas dalam satu pembelajaran membaca menulis permulaan (MMP).

Orientasi pembelajaran membaca permulaan berupa melek huruf Mulyati (2011). Melek huruf yang dimaksud adalah kemampuan melafalkan lambang-lambang huruf tanpa disertai dengan pemahaman dari bunyi-bunyi lambang tersebut. Selanjutnya agar peserta didik yang masih pada tahap melek huruf dibina dan dituntun agar peserta didik tidak sekedar memiliki kemampuan melafalkan lambang-lambang huruf tetapi disertai juga dengan pemahamannya terkait dengan bunyi-bunyi dari lambang yang dilafalkan. Penekanan membaca permulaan menekankan pada teknis membaca Hamalik (2006). Teknis membaca yang ditekankan pada aspek-aspek pembelajaran membaca permulaan ketepatan dalam membaca seperti ketepatan intonasi, ketepatan lafal, serta kelancaran dalam membaca. Lafal adalah kemampuan dalam bunyi bahasa yang meliputi vokal, konsonan, diftog, dan gabungan konsonan. Pelafalan yang benar sangat penting untuk diperhatikan karena menentukan makna dari kata yang diucapkan. Vokal disebut juga huruf hidup sedangkan konsonan adalah kebalikannya. Diftong merupakan suku kata yang terdiri dari bunyi vokal rangkap. Intonasi merupakan tinggi rendahnya nada dalam suatu kalimat.

Selain melek huruf yang ditekankan pada peserta didik kelas awal, peserta didik juga memiliki kemampuan nurturant effect yaitu menanamkan budaya literasi kepada peserta didik sehingga bisa mengembangkan keterampilan berbahasa. Keterampilan berbahasa merupakan keterampilan yang berkomunikasi antara satu orang atau lebih melalui perantara bahasa baik secara lisan maupun tulisan. Ada empat aspek yang ada dalam pembelajaran membaca permulaan yang saling berkaitan antara satu dengan yang lainnya yakni lafal, intonasi ketepatan, kelancaran serta kejelasan suara. Ketepatan membaca permulaan adalah pengucapan yang sesuai atau pengucapan dengan benar kata atau kalimat yang dibaca. Peserta didik dikatakan lancar membaca jika peserta didik bisa membaca kata atau kalimat tanpa terbata-bata dan meyakinkan. Pada saat peserta didik bisa membaca dengan jelas dan nyaring sehingga bisa di dengar oleh peserta didik yang lainnya maka peserta didik tersebut sudah dikatakan pada aspek kejelasan. Keempat aspek membaca permulaan sangat penting untuk diperhatikan. Tingkat kemampuan membaca permulaan peserta didik bisa diketahui dari seberapa besar aspek yang sudah peserta didik capai dalam membaca permulaan. Membaca permulaan bisa tepat dilakukan dengan memperhatikan aspek-aspek membaca permulaan yang sudah dicapai oleh peserta didik.

Hal lain yang perlu diperhatikan dalam pembelajaran membaca permulaan yaitu fonem, alfabet, kelancaran, kosa kata dan pemahaman. Pembelajaran membaca permulaan bukanlah hal yang mudah untuk dilakukan oleh seorang guru dan membutuhkan begitu banyak kesabaran Hasanudin (2016). Jadi. Dalam pembelajarannya ada beberapa hal yang perlu untuk diperhatikan oleh seorang guru diantaranya [1] ketepatan mengucapkan lambang tulisan menjadi bunyi, [2] ketepatan dalam menggunakan frase, [3] ketepatan intonasi, [4] memiliki kebiasaan dalam merawat buku dengan baik dan rapi, [5] mengenal berbagai macam tanda baca yang sederhana. Sehingga dalam hal ini keterampilan guru dalam memgajar sangat diperlukan karena mengajar membaca permulaan bukanlah hal yang mudah. Ada beberapa hal yang menjadi pertimbsngsn bsgi guru sgsr bisa memenuhi kebutuhan peserta didik dalam membaca permulaan. Kreativitas guru dalam mengajar harus dikembangkan karena peserta didik di kelas awal cepat merasa bosan dalam belajar. Apabila pembelajaran bisa menarik peserta didika maka tujuan pembelajaran akan tercapaik dengan baik. Berbagai macam cara sudah dilakukan oleh guru dalam mengajarkan membaca permulaan secara inovatif dan hasilnya masih ada beberapa peserta didik belum memiliki kemampuan yang bagus dalam membaca permulaan. Hal ini disebabkan karena latar belakang peserta didik yang berbeda-beda baik dari segi kecerdasan, ekonomi, sosial dan budaya Abbas (2010).

Kemampuan membaca peserta didik di kelas awal belum 
hanya berfokus untuk membacanya tanpa memahami isi bacaan yang dibaca Abidin (2010). Biasanya peserta didik memerlukan waktu yang berlangsung selama dua tahun dalam memperoleh kemampuan membaca permulaan yaitu pada jenjang kelas satu dan kelas dua sekolah dasar. Pada tahap membaca permulaan peserta didik di kelas awal dihadapkan pada materi mengenai mengenai sistem tulisan, cara mencapai kelancaran membaca, memusatkan kata-kata lepas dalam cerita sederhana dan belajar mengintegrasikan bunyi dan sistem tulis berdasarkan kajian dari Slavin (2014). Setelah peserta didik menguasai membaca permulaan maka akan diteruskan dengan kemampuan membaca selanjutnya. Melalui membaca segala macam informasi bisa memperoleh dan memahami segala informasa yang dibaca. Sehingga bisa dikatakan bahwa membaca adalah kemampuan yang sangat penting untuk dikusai oleh peserta didik. Kemampuan awal yang harus dikuasai oleh peserta didik adalah kemampuan membaca permulaan sebagai dasar untuk menuju ke tahap membaca selanjutnya Triyadi et al. (2019). Kemampuan membaca tidak hanya melibatkan mata pelajaran bahasa indonesia saja tetapi juga tetapi seluruh mata pelajaran yang lain karena membaca tidak hanya digunakan pada saat mendapatkan pelajaran bahasa indonesia Zubaidah (2013). Ketika membaca maka kita mendapatkan informasi dari apa yang kita baca sebagai produk dari membaca. Namun, pada tahap membaca permulaan yang ditekankan adalah melek huruf. Kemapuan membaca permulaan berbeda dengan kemampuan membaca pemahaman yang diperoleh oleh peserta didik ketika sudah pada kelas tinggi. Pada tingkat pemahaman perserta didik dituntut untuk bisa memahami isi bacaan sedangkan pada membaca permulaan yang menjadi fokus pembelajarannya adalah dasa-dasar dari membaca. Dasar-dasar membaca yang dimaksudkan yaitu melafalkan lambang-lambang bunyi bahasa tulis. Jelas bahwa antara membaca permulaan dengan pembelajaran membaca di kelas tinggi berbeda dari berbagai aspek salah satunya dari segi materi dan dari tingkatan kelas antara kelas awal/kelas rendah $(1,2,3)$ dengan kelas tinggi $(4,5,6)$. Peseta didik tidak bisa mengikuti tahap membaca pemahaman sebelum memiliki kemampuan membaca permulaan.

Tahap membaca permulaan sangat penting untuk dikuasai karena ketepatan dan keberhasilan pada tahap membaca permulaan akan berdampak besar terhadap peningkatan kemampuan membaca selanjutnya. Siswa yang tidak mampu membaca dengan baik akan mengalami kesulitan dalam mengikuti kegiatan pembelajaran Rahim (2005). Dalam hal ini, membaca merupakan kemampuan yang harus dikuasai siswa di sekolah dasar karena kemampuan membaca secara langsung berkaitan dengan seluruh proses belajar siswa Rahim (2005). Dalam pembelajaran membaca permulaan peserta didik akan belajar untuk mengenal huruf dimana setiap huruf mempunyai bentuk dan nama yang berbeda. Kemudian huruf tersebut yang terdiri dari huruf vocal dan huruf konsonan dilafalkan sesuai dengan bunyinya. Selanjutnya peserta didik akan diperkenalkan untuk pada langkah mengeja suku kata, membaca kata, dan membaca kalimat pendek berdasarkan pendapat Dal- man (2014). Misalnya : saya peserta didik mengeja suku /sa/ dan suku /ya/ sehinga dibaca saya. Peserta didik juga dititik beratkan pada penguasaan bersifat tekhnik yang bertujuan melatih siswa menyuarakan lambang-lambang tulisan dengan tepat, lafal yang baik, serta intonasi yang wajar menurut Rosdiana dkk, (2011).

Dalam proses pembelajarannya, kemampuan membaca permulaan tidak mudah untuk dikuasai dengan mudah. Banyak peserta didik yang mengalami kesulitan-kesulitan belajar yang menghambat kemampuan membaca permulaan. Kesulitan yang dialami peserta didik menimbulkan beberapa kesalahan-kesalahan. Peserta didik biasanya melakukan kesalahan saat membaca tulisan yang disertai dengan beberapa huruf yang berbeda Fauziyah et al. (2017) Bisa dikatakan kesalahannya adalah tidak bisa membedakan huruf atau salah dalam mengenal huruf, misalnya membedakan antara huruf /b/ dengan huruf /d/. Bagi pembaca pemula kedua huruf ini terlihat mirip jika tidak dicermati dengan baik. Setiap peserta didik mengalami kesulitan belajar yang berbeda-beda. Berikut beberpa kesulitan-kesulitan membaca yang tejadi pada peserta didik yaitu pertama cara membaca, kedua kurang mengenal kata, ketiga kekeliruan pemehaman, keempat gejalagejala serbaneka (Adurrahman, 2013). Untuk menanggulangi hal ini seorang guru harus memahami kebutuhan peserta didik sehingga bisa memberikan metode yang tepat dalam pembelajarannya.Cara untuk mengetahui kesulitan belajar yang dialami oleh peserta didik dalam membaca permulaan adalah dengan analisis sebab-sebab terjadinya kesulitan membaca permulaan yang dialami oleh peserta didik. Kesulitan membaca permulaan yang dialami peserta didik dapat tampak ketika peserta didik melakukan kesalahan saat membaca sehingga seorang guru harus mencermati setiap kesalahan yang dilakukan peserta didik sehingga seorang guru bisa mengetahui jenis kesulistan membaca permulaan yang dialami peserta didik. Anilisis bisa menggunakan lembar proses atau lembar observasi sehingga memudahkan dalam menganalisis kemampuan membaca permulaan peserta didik. Kesulitan peserta didik dalam membaca tidak bisa dilewatkan. Hal ini memerlukan perhatian yang serius karena pentingya kemampuan membaca permulaan. Peserta didik yang megalami kesulitan dibina dan dituntun agar tujuan pembelajaran bisa tercapai dengan baik. Jadi dalam hal ini peseta didik diberikan kalimat sederhana untuk dibaca kemudia guru menyimak peserta didik ketika membaca. Ketika membaca pasti akan tampak kesulitan-kesulitan yang dialami. Hal yang perlu dicermati untuk mengetahui kesalahan-kesalahan yang dikakukan peserta didik saat membaca adalah dengan memperhatikan lafal, intonasi, kelancaran, ketepatan dan kejelasan suara.

Analisis kemampuan membaca permulaan terhadap peserta didik di kelas awal bertujuan untuk mengetahui sejauh mana kemampuan peserta didik dalam membaca permulaan sehingga bisa diberikan arahan yang sesuai dengan permasalahan. Selain mengetahui permasalahan dalam membaca permulaan, melalui analisis bisa mengetahui perkembangan kemampuan peserta didik yang sudah bagus dalam 
membaca permulaan. Peserta didik dikatakan mampu membaca permulaan apabila peserta didik sudah memenuhi indikator-indikator kemampuan membaca permulaan. Tentunya untuk mencapai kemampuan membaca permulaan yang baik memerlukan proses yang cukup sulit. Seperti kita ketahui bahwa kemampuan membaca permulaan adalah proses pembelajaran yang sulit dan membutuhkan kesabaran yang cukup tinggi. Jika siswa kelas I sudah menguasai tahap kemampuan membaca permulaan maka siswa bisa melanjutkan ke tahap membaca selanjutnya yaitu tahap membaca lanjut. Sesuai dengan penelitian Pratiwi,dkk yang menganalisis kesulitan membaca permulaan di kelas I SD Lembang menunjukkan bahwa ada beberapa kesulitan atau ketidakmampuan siswa dalam membaca permulaan. Berdasarkan hal tersebut peneliti ingin melakukan penelitian untuk menganalisis kemampuan membaca permulaan di kelas I SD Negeri 3 Ubud.

\section{METODE}

Penelitian ini dirancang dengan pendekatan penelitian deskriptif kualitatif. penelitian kualtatif adalah penelitian untuk memahami fenomena tentang apa yang dialami oleh subjek penelitian dengan cara deskripsi dalam bentuk katakata dan bahasa berdasarkan pada hasil pengamatan Margono (2014) penelitian ini mendeskripsikan tentang segala sesuatu yang berkaitan dengan realitas yang ada di lapangan tentang analisis kemampuan membaca permulaan siswa kelas I SD Negeri 3 Ubud. Jadi penelitian ini bertujuan untuk mengetahui kemampuan membaca permulaan pada siswa kelas I SD Negeri 3 Ubud.

Penelitian ini dilaksanakan di SD Negeri 3 Ubud.Penelitian ini mengambil lokasi ini karena (1) untuk memudahkan terciptanya kolaborasi antara peneliti, siswa, dan guru-guru lainnya, (2) peneliti sudah mengenal situuasi guru-guru yang ada dan (3) kondisi sekolah secra umum sudah dikenal. Tahap penelitian ini memiliki berapa langkah yang harus dilakukan yaitu tahap pengumpulan data, penulisan laporan dan release. Ada beberapa teknik pengumpulan data yang digunakan dalam penelitian ini yaitu observasi, dan tes. Observasi adalah proses melihat, mengamati, mencermati, dan merekam perilaku secara sistematis untuk memperoleh data sehingga dapat digunakan untuk memberikan suatu kesimpulan atau diagnosiss Suharsaputra (2014).

Tes adalah alat yang digunakan untuk mengetahui atau mengukur sesuatu dalam suasana, deengan cara dan aturanaturan yang sudah ditentukan. Menurut Agun (2014) "tes adalah cara memperoleh data yang berbentuk suatu tugas yang harus dikerjakan oleh seorang atau sekelompok orang yang dites (testee), dan dari tes dapat menghasilkan suatu skor (interval). Sejalan dengan pendapat tersebut Sanjaya (2014) berpendapat tes adalah instrument atau alat untuk mengumpulkan data tentang kemampuan subjek penelitian dalam menguasai materi pelajaran tertentu. Sedangkan instrumen penelitian yang digunakan adalah lembar observasi, tes dan rubrik. Lembar observasi adalah selembar kertas yang berisi aspek terkait dengan poin-poin utama yang akan diteliti. Lembar observasi digunakan untuk mengumpulkan data dari proses belajar mengajar dan dari dokumen penelitian.

Untuk mengecek keabsahan data dilakukan dengan teknik pengecekan teman sejawat dan triangulasi. Triangulasi yang dilakukan adalah triangulasi metode dan triangulasi peneliti.Triangulasi metode dilakukan untuk mengkonfirmasikan data. Data yang diperoleh dari hasil observasi jika diperlukan akan dilakukan triangulasi kepada pakar dan teman sejawat melalui diskusi. Hasil diskusi akan diklarifikasi.riangulasi oleh tim peneliti akan dilakukan setelah selesai pembelajaran jika dipandang perlu.

Semua data yang terkumpul akan dianalisa secara deskriptif menggunakan metode kualitatif dan kuantitatif. Data dalam penelitian ini berupa data kualitatif dan data kuantitatif. Hasil observasi diseskripsikan secara kulaitatif. Data yang dihasilkan melalui tes dideskripsikan secara kuantitatif dan kualitatif. Dalam penelitian ini untuk mengukur kemampuan membaca siswa dilakukan melalui tes membaca. Tes membaca yang diberikan adalah siswa diminta untuk membaca teks sederhana di depan kelas. Data dianalisis dengan teknik skala Likert . Menurut Sugiyono (2012) skor ini kemudian dikonversi kedalam persentase dengan menggunakan rumus: $p=\frac{f}{n} \times$ $100 \%$, dengan $\mathrm{p}$ adalah prosentase, $\mathrm{f}$ adalah frekuensi skor tiap angket, $\mathrm{n}$ adalah skor ideal, dan 100 adalah bilangan tetap. Dalam penelitian ini juga dilakukan pendokumentasian berupa foto. Foto ini dijadikan bukti otentik bahwa pembelajaran benar-benar berlangsung.

\section{HASIL DAN PEMBAHASAN}

Penelitian ini menggunakan siswa kelas 1 SD yang berjumlah 22 orang sebagai sampel. Berdasarkan rekapitulasi hasil penelitian diperolehlah skor total kemampuan membaca permulaan untuk seluruh siswa sebesar 1820 dengan rata-rata 82,73. Pemaparan hasil ada pada Tabel 1

\section{[Table 1 about here.]}

Hasil penelitian ini didukung oleh penelitiannya Muslimin et al. (2018). Hasil penelitiannya mengungkapkan bahwa penerapan metode SAS dapat meningkatkan kemampuan membaca permulaan siswa kelas 1 MIS Sinoutu yang dibuktikan dengan adanya peningkatan tingkat kemampuan membaca dari siklus I ke siklus II, dengan persentase daya serap klasikal adalah $68,9 \%$ pada siklus I dan $90 \%$ pada siklus II. Persentase ketuntasan klasikal adalah $60 \%$ pada siklus I dan $90 \%$ pada siklus II. Penelitian yang serupa juga dilakukan oleh Irdawati, dkk (2018). Hasil penelitiannya mengungkapkan bahwa meningkatnya kemampuan membaca awal dengan menggunakan media gambar di kelas 1 Min Buol mencapai hasil yang sangat memuaskan dengan kriteria sangat baik (sangat meningkat) dari siklus I ke siklus II. Pada siklus I diperoleh skor 71 dengan kategori kurang meningkat, 
sedangkan pada siklus II diperoleh skor 92 dengan kriteria sangat meningkat. Penelitian Partikasari (2016) juga menemukan bahwa terjadi peningkatan membaca permulaan dari $47 \%$ yang tergolong dalam kriteria kurang baik menjadi $82,8 \%$ yang tergolong dalam kriteria sangat baik pada siswa PAUD AL-Anisa Bnetiring dengan menggunakan metode Flas Card SUBACA. Metode ini ternyata terbukti mampu meningkatkan kemampuan membaca permulaan anak usia dini. Dengan demikian di SD N 3 Ubud yang memiliki ketuntasan persetujuan 85\% masih memungkinkan untuk bisa ditingkatkan lagi kemampuan membacanya dengan memberikan perlakuan belajar tertentu yang secara alami dapat dilakukan tanpa menekan kebebasan anak untuk belajar. Dengan memberikan materi yang sederhana yang sedang hangat diperbincangkan masyarakat luas secara otomatis anak akan tertarik untuk membacanya untuk memenuhi rasa ingin tahunya.

\section{KESIMPULAN}

Berdasarkan hasil pengelitian dan pembahasan dapat disimpulkan bahwa kemampuan membaca permulaan siswa kelas I SD Negeri 3 Ubud tergolong baik. Hal ini dibuktikan dengan prosentase perolehan sebesar $85 \%$ dengan skor total adalah 94 dan rerata skor 4,27 yang tergolong baik pada skala 5 dari likert, dengan nilai rerata kelas adalah 82,72. Faktor-faktor yang menjadi penyebab beragamnya kemampuan membaca pada siswa kelas 1 SD N 3 Ubud belum sempat diteliti karena

\section{REFERENCES}

Abbas, S. (2010). Penerapan Pembelajaran Model Time Game Tournaments (TGT) Berbantuan Peraga Suku Kata Bentuk Domino untuk Meningkatkan Keterampilan Membaca Permulaan Siswa Kelas I MIN Subagan Karangasem Tahun Pelajaran. doi: SPKDIPAFALKUTAS0159/023/xx/2010.

Abidin, Y. (2010). Strategi Membaca Teori Dan Pembelajarannya (Bandung: Risqi Press).

Agun, A. A. G. (2014). Pengantar Evaluasi Pendidikan (Singaraja: Universitas Pendidikan Ganesha).

Dalman (2014). Keterampilan membaca (Jakarta: Raja Grafindo Persada).

Fauziyah, M. U., Hamdu, G., and Apriliya, S. (2017). Bentuk- Bentuk Kesalahan Membaca Siswa SD Kelas Rendah. Pedadidaktika: Jurnal Ilmiah Mahasiswa Pendidikan Guru Sekolah Dasar 4, 150-157.

Hamalik, O. (2006). Proses Belajar Mengajar (Jakarta: PT.Bumi Aksara).

Hasanudin, C. (2016). Pembelajaran Membaca Permulaan dengan Menggunakan Media Aplikasi Bamboomedia Bmgames Apps Pintar Membaca Sebagai Upaya Pembentukan Karakter Siswa SD Menghadapi MEA. PEDAGOGIA: Jurnal Pendidikan 5, 1-1. doi: 10.21070/pedagogia.v5i1.84.

Margono, S. (2014). Metode Penelitifzan Pendidikan (Jakarta: Rineka Cipta).

Masykuri (2019). Analisis kesulitan membaca permulaan pada siswa kelas I MI Pesantren Pembangunan Cibeunying Kecamatan Majenang Kabupaten Cilacap tahun. http://eprints.walisongo.ac.id/9751/1/SKRIPSI\%20FULL.pdf.

Mulyati, Y. (2011). Modul Membaca Menulis Permulaan (Bandung: Universitas Pendidikan Indonesia).

Muslimin, Tahir, M., and Patekkai, I. (2018). Peningkatan Kemampuan Membaca Permulaan Siswa Kelas I MIS Sinoutu Melalui Metode Struktural Analitik Sintetik (SAS). Jurnal Kreatif Tadulako Online 2, 50-57.

Rahim, F. (2005). Pengajaran Membaca di Sekolah Dasar (Jakarta: Bumi Aksara). keterbatasan jangkauan penulis. Demikian pula terhadap jumlah sampel yang digunakan masih terbatas pada siswa kelas 1, sehingga bisa dikembangkan lagi untuk kelas 2 dan PAUD jika memungkinkan, termasuk di sekolah dasar lainnya. Untuk itu penulis menyarankan bagi peneliti lain yang berminat dalam mengembangkan penelitian yang sejenis untuk melakukan penelitian dengan variabel, sampel, dan lokasi penelitian yang lebih banyak dalam upaya menggali potensi anak didik di SD, khususnya untuk potensi kemampuan membaca permulaan.

Dengan adanya hasil penelitian ini bisa memudahkan guru sebagai pengajar untuk mengklasifikasikan siswa dalam tingkat kemampuan membaca permulaan. Hal ini mengakibatkan guru-guru dapat dengan mudah memberikan materi yang sesuai dengan tingkat pemahaman membacanya.

\section{UCAPAN TERIMA KASIH}

Rasa terima kasih peneliti ucapkan kepada keluarga besar STKIP Suar Bangli yang sudah memberikan dukungan dalam pelaksanaan penelitian ini baik secara langsung maupun secara tidak langsung sehingga penelitian ini bisa berjalan sesuai dengan harapan. Bagi peneliti-peneliti yang lain yang sudah terlebih dahulu melakukan penelitian yang serupa sehingga peneliti bisa gunakan sebagai bahan kajian yang relevan untuk mengembangkan penelitian ini. Peneliti juga berharap agar peneliti-peneliti yang lain agar bisa melakukan penelitian untuk mengkaji hal-hal yang belum terungkap.

Sanjaya, W. (2014). Strategi Pembelajaran Berorientasi Standar Proses Pendidikan (Jakarta: Prenadamedia), 1-294.

Slavin, R. E. (2014). Membaca Membuka Pintu Dunia Program Sukses For All Model Yang Jelas Dan Kuat Untuk Meningkatkan Kemampuan Membaca Anak Sekolah Dasar (Yogyakarta: Pustaka Pelajar), 1-562.

Sugiyono (2012). Metodologi Penelitian Kuantitatif, Kualitatif, dan Penelitian Tindakan Kelas (Bandung: Bandung).

Suharsaputra, U. (2014). Metode Penelitian Kuantitatif Kualitatif dan Tindakan (Refika Aditama: Bandung).

Triyadi, S., Rozak, R. W. A., Tantowi, Y. A., Tantowi, Y. A., and Supriatna, E. (2019). Analisis Kemampuan Membaca Permulaan Dan Pemanfaatannya Dalam Merancang Pembelajaran Literasi Awal Berbasis Fabel. Program Pasca Sarjana: Proceeding Humanis Pamulang 1, 78-85.

Zubaidah, E. (2013). Kesulitan Membaca Permulaan Pada Anak: Diagnosa dan Cara Mengatasinya (Universitas Negeri Yogyakarta: Pendidikan Guru Sekolah Dasar).

Conflict of Interest Statement: The authors declare that the research was conducted in the absence of any commercial or financial relationships that could be construed as a potential conflict of interest.

Copyright (C) 2021 Janawati and Sulantara. This is an open-access article distributed under the terms of the Creative Commons Attribution License (CC BY). The use, distribution or reproduction in other forums is permitted, provided the original author(s) and the copyright owner(s) are credited and that the original publication in this journal is cited, in accordance with accepted academic practice. No use, distribution or reproduction is permitted which does not comply with these terms. 


\section{LIST OF TABLES}

1 Pemaparan Hasil Penelitian . . . . . . . . . . . . . . . . . . . . . . . . . . . 
TABLE 1 | Pemaparan Hasil Penelitian

\begin{tabular}{|c|c|c|c|c|c|c|}
\hline No & Rumus & Skala & Nilai & Skala Jawaban X Nilai Skala & Hasil & Persentase \\
\hline 1 & $89-100$ & Sangat Baik (SB) & 5 & $8 \times 5$ & 40 & $36,36 \%$ \\
\hline 2 & $67-88$ & Baik (B) & 4 & $12 \times 4$ & 48 & $54,55 \%$ \\
\hline 3 & $45-66$ & Cukup Baik (CB) & 3 & $2 \times 3$ & 6 & $9,09 \%$ \\
\hline 4 & $23-44$ & Kurang Baik (KB) & 2 & & & \\
\hline 5 & $0-22$ & Sangat Kurang Baik (SKB) & 1 & & & \\
\hline \multicolumn{5}{|c|}{ TOTAL } & 94 & $85 \%$ \\
\hline
\end{tabular}

